\title{
Music, Eurocentrism and Identity: The Myth of the Discovery of America in Chilean Music History*
}

\author{
Alejandro Vera \\ Music Institute, Pontificia Universidad Católica de Chile, Santiago, Chile \\ Email: averaa@uc.cl
}

Received 26 August 2014; revised 18 November 2014; accepted 26 November 2014

Copyright (C) 2014 by author and Scientific Research Publishing Inc.

This work is licensed under the Creative Commons Attribution International License (CC BY). http://creativecommons.org/licenses/by/4.0/

\begin{abstract}
During the past century, Edmundo 0'Gorman, Tzvetan Todorov, Enrique Dussel and other scholars pointed out the Eurocentric perspective implied in traditional narratives about the discovery of America, most of which intended to confirm Europe as the center of world history and culture. At the same time, Claude Lévi-Strauss, Hayden White and others argued for the mythical character of history. According to them, even though historians attempted to assemble documentary evidence objectively, they constructed their narratives incorporating such evidence in preexisting stories, characters and categories with a mythical origin. This paper uses these viewpoints to analyze and criticize the way in which Chilean music history has been constructed, particularly during the republican era. The main hypothesis is that traditional discourses about that history have constantly recycled narratives on the discovery of America, which thus operates as a kind of founding myth for historical and musicological interpretations, especially when dealing with turning points such as the change of dynasty (1700), the beginning of independence (c. 1810) and the centenary of the republic (1910). A corollary would be that documentary evidence about music has been frequently hidden or distorted precisely in order to fit such a myth. That is why the present paper examines both bibliography and original documents found in different archives.
\end{abstract}

\section{Keywords}

Music, History, Chile, Discovery of America, Eurocentrism

\footnotetext{
*Preliminary versions of this article were presented at the I Encuentro de investigadores en música antigua y colonial (Santiago de Chile, 28 August 2009) and the 19th Congress of the International Musicological Society (Rome, 2 July 2012).
} 


\section{Introduction}

In a work published originally in 1949, the philosopher Mircea Eliade affirmed the following:

"The recollection of a historical event or a real personage survives in popular memory for two or three centuries at the utmost. This is because popular memory finds difficulty in retaining individual events and real figures. The structures by means of which it functions are different: categories instead of events, archetypes instead of historical personages. The historical personage is assimilated to his mythical model (hero, etc.), while the event is identified with the category of mythical actions (fight with monster, enemy brothers, etc.). If certain epic poems preserve what is called "historical truth", this truth almost never has to do with definite persons and events, but with institutions, customs, landscapes... The memory of the collectivity is anhistorical” (Eliade, 1971: pp. 43-44) ${ }^{1}$.

As we can see, Eliade attributed a mythic condition to oral or traditional memory, while history, as a discipline would be different because it is based on documents that provide precise and detailed information.

In contrast to this view, Claude Lévi-Strauss suggested, as early as the 1960s, that written history is also mythic in nature given that any two historians, even when they use the same documental data, "reveal” them in very different ways. This happens because of the inevitable gaps that documents contain, which must necessarily be completed by the historian through inferences and conjectures with the aim of providing meaning to disperse data. From this perspective, the act of chronicling history has an unavoidable interpretative character and the validity of the data is not a result of the data itself so much as a product of the capacity of the historian to integrate them into a coherent story. However, the coherence of such a historic narrative is of a mythic nature given that it generally cannot be demonstrated empirically; but is given only by its proximity to other accounts (read other myths), known and accepted by both the historians and their potential readers (White, 1973: pp. 288-289) ${ }^{2}$. In other words, while it is true that historians work with more precise data than those of the popular memory, when they come to interpreting these, they do so framing the data in already familiar mythic structures, similar to those that popular memory employs: archetypes instead of personages, categories instead of events, etc. And this, which might seem to go against a historical science in the strict sense, may prove necessary for its development given that if a researcher were incapable of linking the evidence discovered to what is already known he would probably not be able to understand it and therefore could not contribute to new knowledge.

The approach of Lévi-Strauss served Hayden White in proposing that history presents important similarities to a fictional story, to the extent that the past we want to know comes to us through texts (documents) and consequently already interpreted, that is, already mythified. Thus, the relationship of the historian to historical facts is not direct, but rather is mediated, not only by his own vision of the world, but also by the vision of those who wrote the documental testimonies that serve them as base. To a great measure, history is a discursive construction (White, 1973: pp. 281-314).

Gabriel Castillo has dealt with similar ideas in the field of Latin American music. His main argument is that, while musicological discourses about this music are constructed from a supposedly preexisting musical experience, it is eventually impossible to identify any musical expression without making reference to the discourses (terms and ideas) musicology has built to legitimize its existence. According to this perspective, musical identity would be predetermined by musicological discourses, in a relation of mutual reciprocity (Castillo, 1998: p. 15) ${ }^{3}$.

These theoretical premises have proven useful to understand certain processes that would otherwise have gone unnoticed. Replacing musical expression/identity with music history, and musicological discourse with historiographical debate, this article assumes Castillo's contention that music history is to some extent a discursive construction from the present. This explains, among other things, that its subtitle speaks of "Chilean music history” instead of "Chilean music historiography”, since both are considered as two sides of the coin, one implying each other (see also, in this respect, Treitler, 1990).

Nevertheless, the concept of history that predominates in these pages is somewhat different. For the present

\footnotetext{
${ }^{1}$ Cited from the Spanish edition by Cristian Guerra (2008: pp. 213-214).

${ }^{2}$ An application of the theories of Lévi-Strauss about myths to analyse music can be found, among others, in the work of Michael L. Klein (2005: pp. 27-29).

${ }^{3}$ It is worth noting that contemporary musicology has shown that even disciplines or methodologies traditionally considered as "descriptive", are actually interpretive in their nature. For example, the ideas commented above are reminiscent of what Georg Feder called the "hermeneutic circle" in the field of music edition: "We must know the meaning of the symbols before we can transcribe them in order to ascertain their meaning” (cited by Grier, 1996: p. 58).
} 
author, as for others, the discursive or textual dimension referred to by Lévi-Strauss, White and Castillo constitutes only a part of history that should be placed in dialogue with its factual dimension, that is, with the historical facts which we can glimpse through the sources of the studied epoch; and much as the nature of the latter is also discursive, no one can doubt that the events that produced them had a real existence (Hutcheon, 1988: pp. $16,128,143)$. This theoretical perspective is also aligned with recent tendencies in the study of music, history and culture that show an increasing awareness about the inadequacy of textual analysis if it is not accompanied by some kind of documental or "social verification" (Fulcher, 2011: pp. 4-5). In methodological terms, this is reflected by combining the critical analysis of the historiographical discourse with a detailed study of the documentary evidence, without neglecting one for the other.

More specifically, the present study addresses the relationship between the history of music in Chile and one of the central myths in the history of the "west", as is the discourse around the discovery and conquest of America. Dussel considers it to be the foundational myth of modernity, the moment in which Europe becomes conscious for the first time of the other and the complex task begins of covering it up (Dussel, 1992; pp. 9-10); and Todorov considers it the most astonishing encounter of history, the event that founded and announced our present identity (Todorov, 1984: pp. 4-5). The main hypothesis is that many of historical accounts about music in Chile represent variants of this myth, in particular when they attempt to explain the most relevant processes of change. It is claimed that they have been constructed from evidence, but in reality they have based on pre-existing mythic stories that are implicitly accepted as valid. To verify this, we shall analyze some of these stories and contrast them with historical documents that show us how even what we call "hard data" were often adjusted by the scholars with the aim of fitting them to the myth.

These hypotheses seek to complement rather than substitute or discard others that have been formulated around Chilean musical historiography, like those centered on the exclusion of popular cultures that we owe to Maximiliano Salinas (2000) ${ }^{4}$, and that based on nationalism forwarded by this author (Vera, 2006, 2010). At the same time, I hope to show that the study of the colonial epoch and the nineteenth century can also illuminate more contemporary periods of the history of music, as well as contributing to a better understanding of the mode in which we are writing this history.

\section{The Myth}

In the strict sense, just to speak of the discovery of America implies mythologizing history. The term reminds us of the planetary discoveries; Pluto was effectively discovered in 1930 in that it was not known by humans before that. Consequently, its use and acceptance supposed forgetting the fact that people previously lived in America. In this way, aboriginal societies were relegated to an undefined space, while Europe was universalized and stood as the representative culture of the West, incarnating the only valid model of civilization by the time (cf. Castillo, 1998: p. 18). The city, the literacy, the divine cult and political religious institutions represented then civility by excellence, while the other (disperse indigenous people on the plains, other religious beliefs...) were qualified with terms such as chaos or barbarism (Waisman, 2005: pp. 160-163), and better understood by negation, that is, as uncivilized and cultureless manifestations (Castillo, 1998: p. 20). Thus, there are a significant number of colonial testimonies that characterize indigenous music, so to speak, as non-music. I limit myself to the following example of 1658, which comes from the other side of the Andes, in which it is affirmed that the natives responded to the shots fired by the Spaniards "with shouting and with flutes and horns, as they are accustomed to do" (Gesualdo, 1978: p. 3). As Salinas states, the conquest of America was thus transformed into "the articulating event of historical ordering", the moment in which history itself began. In fact, Eugenio Pereira Salas, notwithstanding the valuable information that he provides about indigenous music in Chile, names the chapter dedicated to this theme in his book Los orígenes del arte musical... (1941) as "Music before the conquest" (Salinas, 2000: p. 46).

But even assuming an exclusively European perspective, the concept of discovery is equally inappropriate. For centuries it had been thought that Christopher Columbus undertook his voyage with the aim of finding unknown lands, the existence of which had been deduced thanks to unfolding scientific knowledge. This was the version presented by his son Fernando in the posthumous biography about his father. When Martín Fernández Navarrete edited Columbus' papers in 1825-1837, it was evident that even his last days, Columbus believed that he had reached the eastern coast of Asia and this always constituted his true objective. The only moment in

\footnotetext{
${ }^{4}$ Salinas also draws upon Eurocentrism to explain this exclusion, although his analysis is very different from that presented here.
} 
which Columbus considered the possibility of being before "another world" occurred during his third voyage, when he and his men came upon the northern coast of South America; the abundant presence of fresh water implied the existence of mighty rivers and consequently a continent toward the south, where it had been supposed that there had only been ocean. However, in the end he interpreted these new lands as simply an extension of Asia and more specifically as "that great peninsula that Martin Behaim had drawn in his globe and Henrico Martellus in his planisphere”; that is, as something that was known before. As O’Gorman affirms, we cannot say that Columbus discovered America because we cannot attribute "an act that requires of an agent the awareness of what he is doing” to someone who "lacked this" (O’Gorman, 2004: pp. 26-27, 34, 104-115).

It is worth noting that the version put forward by Fernando Columbus continues to have some force even in our time, almost two centuries after unveiling the true intentions of his father. This shows the first interpretations about a historical event prove determinant for later interpretations and justifies the importance that we are giving in this work to the initial moment of the conquest.

Columbus's belief that he had reached Asia explains that during his first years in the continent he did not discover so much as "verify and identify", making these lands coincide with a prior image of the coasts of the Far East. This image had been formed in part from texts of Ailly, Pliny, Enea Silvio and, above all, Marco Polo that had been published in the fifteenth century. These descriptions of Asia included dragons, monsters and other fantastic beings (Pastor, 1988: pp. 5-8), which contributed to feeding the mythic character of the discovery. Thus, in his reports of November 1492, Columbus declares having heard news a Cyclops and anthropophagus with a dog's snout, and then added in January of the following year having seen three mermaids. Nevertheless, he soon recognized the deception for not having found "monstrous men" (onbres mostrudos) that he had expected to find (Gil, 1989: pp. 42, 47).

But these stories, especially that of Marco Polo, also established the existence of enormous treasures and "civilized” populations with which it might be possible to establish trade (Pastor, 1988: pp. 9-10). In his first voyage, Columbus believes he has reached waters near the island of Zipangu (Japan) and everything he points to about what he has seen is intended to confirm this. The result is deceiving and he begins to characterize the inhabitants he encounters by their defects: In contrast to those described by Marco Polo, the inhabitants of the Caribbean are not dressed, they are not rich, they do not have weapons and they are not traders. However, by his fourth voyage, Columbus claims to have found characteristics similar to the descriptions of Marco Polo in terms of clothing, wealth, trade and weaponry (Ibid., 23-38).

The direct indigenous testimonies, however, never reached the written page: his interlocutor was manipulated and silenced. Indigenous words were even assimilated with others he knew, affirming that they did not know how to pronounce them correctly, as in "Sobo" for "Saba", the region from which the magi came (Ibid., 38-43). In a similar manner, but in the music, Motolinía said in 1540 that the indigenous Americans "also make shawms, although they do not know how to give them the tone they should have"; what could have been understood as a different kind of tuning, is understood as an incorrect tuning (Waisman, 2004: p. 543).

Columbus then took the next step and questioned the capacity of aborigines to speak, stating that they should learn "the language" as though there were no other. This confirms the cultural Eurocentrism that we have already referred:

"Just as a language, that spoken by Columbus, becomes in this discourse the Language against the mutism imposed by the narrator on the natives, the cultural west that the Admiral represents will be presented as the Culture against an implicit indigenous cultural vacuum” (Pastor, 1988: pp. 43-44).

Hence it was very convenient to suppress any glimmer of cultural diversity among the natives, because of which it is not surprising that all the inhabitants of these lands, "culturally virgin" in Columbus's account, appear similar to one another (Todorov, 1984: pp. 35-36).

But while the reference of the admiral is apparently Asia, this has been filtered, since Marco Polo, his contemporaries and Columbus himself has centered their attention on those Asian peoples who most resembled Europeans (Pastor, 1988: p. 46). Consequently, the comparison is apparently to Asia, but the fundamental reference point continues to be Europe. This justifies O'Gorman's view of the so-called discovery as a process of invention, in which the new lands are being designed "to the image and likeness of the conquistador" (O'Gorman, 2004: pp. 54, 151-152). The cultural vacuum that is attributed to them is also related to this, because giving an Asian-European identity to the newly found lands makes the other disappear, since it is not discovered as something new but as something already known. Thus, during the conquest, or at least its initial phase, America was 
“concealed in its Alterity” (Dussel, 1992: pp. 41, 46).

During the $17^{\text {th }}$ and $18^{\text {th }}$ centuries, ideas about the New World and its inhabitants transmitted in the foundational discourse of Columbus remain valid. The writings of the American political thinker Cotton Mather (16631728) show their influence beyond the Hispanic world and the fact that the subjects born in the American continent had assumed them, despite the pejorative connotation that they could have of themselves ${ }^{5}$. For Mather,

“... the coming of the white man meant the beginning of American existence. The wild inhabitants of the continent were seen as part of the natural landscape and their savage state must be replaced by civilization, understood, naturally from a unique point of view, as Western Europe.

America existed as a potential, without meaning until it entered the European awareness... thus it did not have value in its own rights before the Discovery, it was just nature” (Mayer, 1992: p. 21).

In the same sense, at the beginning of the nineteenth century Hegel assigned a physical or geographic immaturity to America and considered it the land of the future; but this implied that there was no present, because of which it could not be the object of philosophical reflection (Dussel, 1992: p. 22).

Even in the twentieth century, when this premises begin to be questioned more consistently by scholars ${ }^{6}$, it is not difficult to find testimonies that evidence the continued validity of the idea of an implicit American cultural vacuum and the superiority of the conqueror. In the Chilean case, Jaime Eyzaguirre repeats such a discourse in the starkest possible:

"What was there in common during millenniums from the sands of the Atacama Desert to the icy boundaries of Antarctica? Nothing more than the wanderings of disparate groups amid nature without unity. The presence of a superior people and the mind of a leader of great vision and temperate will were needed to bring the inert geography to life. Life came into the matter and the dispersed nature came together. Chile thus was born and history began” (Eyzaguirre, 1990: p. 17).

As we can see, the date (1541 instead of 1492), the place (Chile instead of America) and the conquistador (Pedro de Valdivia instead of Columbus) are changed; but in all the rest the discourse is identical to what we have seen in relation to the discovery.

The inescapable weight that these ideas have had and still have on our vision of the world is even more evident when we see them emerging in discourses that are intended to question them. This occurs, for example, with the myth of the noble savage that in general terms configures the discourses of Cortés, Antonio de Montesinos and Bartolomé de las Casas. All of them, to a greater or lesser degree, characterized the natives as "innocent children" that should not be mistreated, but rather protected. But this also implies that they lack the rights of an adult and cannot occupy any place in the colonial system other than that of servant (Pastor, 1988: p. 354).

In a similar manner, but in our times, a critic of Eurocentrism as acute as Enrique Dussel, when he attempts to include America in "a non-Eurocentric vision of world history", does so based on "civilizing systems of urban confederations that we can call great civilizations" (Mayas and Aztecs to the north and Incas to the south) (Dussel, 1992: pp. 101-125), which affirms the view that these societies were superior to the "less developed" cultures and assumes the same differentiating criteria as that of the conquistadors. Likewise, this new vision of history is based on the idea of "consistent progress of humanity", that is, the same principle that has sustained the European centered "universal” history for a long time.

By the same token, it would not be just to demonize Europe as the only one responsible or the depository of these attitudes of incomprehension and intolerance in the period of the conquest or in our times. As Todorov points out, the attitude of Moctezuma is surprisingly similar to that of Columbus, in that it shows the same incapacity to integrate the other in his "system of human otherness", which led initially to including the Spanish in the category of gods. By the time he realized his mistake, he had already lost the battle (Todorov, 1984: pp. 76-77).

In this sense, I believe it is necessary to clarify that it is not my intention to join in a nationalist and anti-European discourse present in certain musicological and academic works in general that seek to match what is American with what is indigenous, leading thus to the absurd idea that the only features pertaining to American culture would be the unique features of it. It is not a question of denying the multiple elements of European origin that have contributed to shape music (and culture) in Chile and Latin America, nor the importance of study-

${ }^{5}$ Gabriel Castillo (2003: p. 84) synthesizes this paradox stating “America adheres to an image of Westernness that consumes, administers and reproduces, although at the cost of not being fully accepted by Westernnesss”.

${ }^{6}$ One of the earliest examples I know can be found in a work by Georg Friederici (1986: p. 9). 
ing them. Nor is it a matter of replacing Eurocentrism (present both in Europe and in Chile and Latin America) with Americanism, indigenism or other ideological slant, given that this would amount to exchanging old orthodoxies for new ones. Rather it is a matter of understanding how Eurocentrism-embodied in the myth of the discovery and conquest of America-has influenced our way of thinking and writing the history of music.

Of course, the problems that the myth of the discovery raises do not stop here, but I believe that the bibliographic review, while it has not been exhaustive, provides us with a sufficient base to synthesize the most representative ideas: 1) Firstly, is the premise of the American cultural vacuum, according to which European culture has been imposed where there wasn't another one; 2) As a consequence of this, the original inhabitants cannot be considered as true agents in the process of incorporating this culture, but rather as passive recipients of the same, thus like all the subsequent processes of cultural change; and 3) As a corollary, the imposition of European culture had a civilizing effect, allowing for the updating and, moreover, the mobilizing of a territory that before had been practically inert and lacked a true history. In the pages that follow I will try to show that there is a profound relationship between these ideas and the music history in Chile, where we see them reappear from time to time as a framework to interpret reality.

\section{Three Recycling of the Myth in the Music History of Chile}

\subsection{The Change of Dynasty (1700)}

Perhaps the first recycling of the myth is related to the Bourbon dynasty assuming the Spanish throne in 1700 . The accession to the throne by a king of French origin led traditional historiography of Spanish music to attribute to this change a negative character, in keeping with its nationalist ideology ${ }^{7}$. Paradoxically, the same ideology led Chilean historiography to interpret such a change positively, since, in a manner of speaking, Spain would have lost its Spanishness (Vera 2010). This was the view of Pereira Salas-perhaps the most influential scholar in subsequent musical historiography-in his important book Los orígenes del arte musical, where he stated:

"The eighteenth century represents the sovereignty of the French spirit in the world... The Spanish rigidity adopts a gala smile... This animated spirit notably influenced the musical arts, given the expansion of instrumental disposition formed a favorable environment for their cultivation.

Among these contributions, we have firstly the harpsichord [clave], which arrived in 1707 on board the

Maurepas... Around this elegant piece grew the first French musical tertulia [gathering]...” (Pereira Salas, 1941: pp. 28-29).

As we can see, there is an insistence in the absolute novelty of these "contributions" and their civilizing character, characteristics that we have seen in the discourses on the discovery. This leads the author to make forced interpretations, as when he affirms that "Spanish rigidity adopts the gala smile", despite having defined the Spanish twenty pages before as “a happy people, enjoyers of life” (Ibid., 8).

But the interpretation that Pereira Salas makes from the turn of the century owes much to another author, whose influence had passed unnoticed for musicology, including the present writer. I refer to Aurelio Díaz Meza, writer, journalist and author of Leyendas y episodios chilenos, a collection originally published in the 1920s and 30s, which contains, in novel form, stories based on chronicles and original documents from different periods. In addition to the important information on music found in several parts of this collection, Díaz Meza dedicates a chapter to the theme entitled "The dawn of musical art in Chile" (Los albores del arte musical en Chile), from which in fact Pereira Salas takes the date of the arrival of the harpsichord or espineta as Diaz Meza called it. The latter adds that this was the first “concert musical instrument” to arrive to colonial Chile (Díaz Meza, 1975: p. 224).

The harmony between the two authors can be appreciated even more in the general assessment they made about the music of the colony. Díaz Meza begins his chapter affirming that in the $16^{\text {th }}$ and $17^{\text {th }}$ centuries there was very little news about cultivating music and that the few data found refer above all to couplets and songs, accompanied by rebec or drum (atambor), concluding that:

${ }^{7}$ A critical review of this vision has been undertaken by Juan José Carreras (2001). A detailed study about the music of the court of Madrid at the beginning of the eighteenth century, with a somewhat different perspective that provides greater weight to the influence of the monarch and his circle in the musical life of time, is owe to Nicolás Morales (2007). 
"It seems superfluous to point out that no trace remains of the rhythm or melody of songs; the musical art in Chile had barely been glimpsed and consequently there was no one able to transcribe the notes of a song; the lyrics of only a few of them have arrived to our day, with which little progress can be made in analyzing the limited musical value that they might have” (Ibid., 223).

As we can see, Díaz Meza favors the exaltation of the supposed obscurantism of the first two colonial centuries, to thus ponder the also supposed changes that the eighteenth century brought about. Claro Valdés places himself in the same vein when he affirms, citing in part Domingo Amunátegui Solar:

"The Chile of the seventeenth century did not reflect European cultural advances, occupied as it was in war and colonization... Nothing was suspected of the great European advances and the Chilean colonists were given the minor chores, full of the terrors of the phenomena of nature and submissively obedient to the royal decrees that arrived from the beyond the sea” (Claro Valdés \& Urrutia Blondel, 1973: p. 45).

In the discourses of both Díaz Meza and Pereira Salas there is an adaptation of what we can call the "hard data”. There is no reason to doubt that a harpsichord arrived in 1707 aboard the Maurepas ${ }^{8}$, but rather the fact that this was the first to arrive. More recent studies have shown, as might be expected, that this instrument by the end of the sixteenth century ended up in the hands of the Augustines, who made frequent use of it between 1595 and 1608 (Vera, 2004a: p. 40; Vera, 2004b: p. 112), as well as in the circle of the governor Oñez de Loyola around 1594 (Alruiz \& Fahrenkrog, 2008: p. 57). Moreover, the cleric Gabriel de Villagra sent a record (información) to the Council of the Indies in 1580 about his merits in order to obtain a sinecure, canonry or curacy in the cathedrals of Santiago or La Imperial. The witnesses confirmed, among other things, that he was "skilled in polyphonic music [canto de órgano] and singing plainsong and the keyboard" (la tecla) ${ }^{9}$. The fact that the document uses the generic term "keyboard" and not the specific term "organ” implies that Villagra had to play different keyboard instruments, among them certainly the harpsichord or clavicordio, as was known at the time ${ }^{10}$. Likewise, Stevenson indicates that another cleric and important musician, Cristóbal de Molina, taught the harpsichord to the mestiza daughter of the conquistador Francisco Pizarro during his stay in Lima. In the 1560s he settled in Santiago, where he remained until his death in 1578 (Stevenson, 1959: pp. 175-176). The fact that he held the position of succentor of the Cathedral makes it more likely that he played this instrument there ${ }^{11}$.

As we can see, a more detailed, but above all, more optimistic review of the sources suggests that this instrument was known in Chile close to the time of the founding of the capital in 1541. The ease with which the interpretation about the harpsichord arrival in the eighteenth century has been accepted reflects not only the lack of thoroughness in the documentary review, but also its adaptation to the mythic system with which scholars have interpreted the turning of the century as the moment in which Chile was transformed in cultural terms. Alfredo Jocelyn-Holt, for example, argues that the fact of having had to wait until 1707 to know the harpsichord demonstrates his thesis that before we were outside "all the circuits" (Jocelyn-Holt, 2004: p. 282).

It is also very debatable to attribute, as Pereira Salas does, an absolute originality to the tertulias. During the previous centuries we find different types of instruments in the private realm, such as vihuelas, guitars and harps, which undoubtedly were used, at least in part, in private gatherings. As examples, we can cite, among others, a vihuela belonging to Jerónimo Bermúdez, which by 1587 was found in the hands of Antón de Guzmán; another belonging to Francisco de Saucedo in 1605; and another belonging to Juana de Oses that was sold to Francisco Ramírez in 1665 after her death ${ }^{12}$. But the documents that best reveal the intense practice of the vihuela in this epoch are the receipts of merchants in which we find an abundance of "vihuela strings". The two most notable examples that I have found, among others that could be mentioned, are the 45 dozen vihuela strings that Jeróni-

\footnotetext{
${ }^{8}$ However, not having found the original document, some incoherencies in the text of Pereira Salas would make it prudent to maintain a certain degree of caution. Although he cites the chapter "Los albores...", the information that he offers does not coincide with everything, so Díaz Meza alludes to the harpsichord that Gabriel Cano de Aponte brought in 1717 and not to that of Ibáñez y Peralta in 1707.

${ }^{9}$ Archivo General de Indias, Chile 64. As evidenced in other documents, Villagra was successful with this petition given that later he appeared as a priest (cura) and succentor (sochantre) of Santiago cathedral. See Archivo General de Indias, Chile 63, letter from the cathedral council to the king (05-12-1585). Other information about Villagra has been published by Pereira Salas (1941: pp. 14-15), and Tomás Thayer Ojeda (1921: p. 54).

${ }^{10}$ On these important differences to current terminology, see among others the study by Beryl Kenyon de Pascual (1992).

${ }^{11}$ His position as succentor of the cathedral of Santiago was mentioned by José Toribio Medina (1906: p. 540) and is confirmed in the Archivo Nacional Histórico, Bienes de difuntos, vol. 1, ff. 89, 94 and others.

${ }^{12}$ Archivo Nacional Histórico, Escribanos de Santiago, vol. 3, f. 396v; vol. 35bis, f. 159; and vol. 264, f. 28.
} 
mo de Molina sold to Jorge Griego on July 8, 1592, and the 23 dozen that Juan de Gastelu sold to Juan Bautista Canobio on April 4, $1594^{13}$.

In terms of the guitar, we have found it predominantly in its small size and higher pitch form, which in that epoch was called the discante ${ }^{14}$. We find one in the hands of the Indian woman Catalina de Alvarado in $1600^{15}$, and a "large discante" - which can seem a contradiction—owned by Josefa Mejía de Guevara in $1665^{16}$. We could also identify this instrument as the guitarrilla that the indio cuzco Agustín de Colliguazo owned in 1604 and the "small guitar" that Bartolomé Carrasco had in $1658^{17}$. As well, the merchant Blas Pinto de Escobar had "five discantes from Lima" in his store in $1635^{18}$, which shows that the instrument was used with sufficient frequency to be imported.

The same is true for the harp. We find it in private hands in the second half of the seventeenth century, such as doña Josefa de Alarcón, who owned one around 1674, Constanza Chacón around 1675 and Mariana Carreto in $1676^{19}$.

Paradoxically, it is Díaz Meza himself who provides a context for the performance of these and other instruments when he affirms that at the end of the seventeenth century, during the government of Tomás Marín de Poveda (1692-1700), the custom "began, or became more constant" that at least every fortnight a sarao was held in the home of a member of the local aristocracy, but without warning him. This was termed a malón, using an indigenous word that meant a surprise attack or raid. As an example, he mentions the malons that took place during one particular year (without saying which) under this government. The first was made upon the treasurer Pedro de Torres and was organized by his daughter, the Countess of Sierra Bella. The second was made upon the Marquis de la Pica, Francisco Bravo de Saravia, whose granddaughter, María Norberta, recently arrived from Lima, not to be outdone had "a priest and a layman who were eminent in the spinet and the rebec" go to her home in the Cañada sector across from San Francisco to play pavans and minuets, as was the custom to open the dancing party. The third was in the home of Andrés de Toro Mazote, also in the Cañada sector. Díaz Meza subsequently described the malón in the home of Licenciado Cerda, where the celebrants arrived unexpectedly with shouts of "malón, malón to the licenciado..." They crossed the first paved courtyard, banging on doors and windows with shouts and cheers, "while Dominga Flores and her three Chinese women launched their strong and experienced voices into the air to the sound of a serenade with harp and guitar. Dominga was the best singer in Santiago and the required participant in parties organized in aristocratic circles. With fair sum of eight pesos she and her daughters animated any party, singing tonadas and sajurias throughout the night” (Díaz Meza, 1975: pp. 145-147).

Although the use of terms related to the contemporary folklore could lead us to question the correctness with which Díaz Meza employs them, as well as the contradictions and errors that can be found in his Leyendas $y$ episodios... ${ }^{20}$, it is also clear that comparison with other sources allows us to verify the accuracy of much of the information he provides ${ }^{21}$. Thus, contrary to the obscurantist diagnosis he made in the chapter about music, the image he projects about the seventeenth century is of a period in which private parties were not the exception. This explains the presence of musical instruments in the inventory of goods from the epoch and at the same time, shows that the tertulias from the beginning of the eighteenth century were far from representing an absolute novelty.

Finally, for those who think that the interpretations mentioned about 1700 as a sort of cultural awakening are no longer valid today or remain limited to an exclusively academic circle, a single fact is sufficient to show the contrary. The website "Memoria Chilena", perhaps the most influential in disseminating ideas about the history of Chile among the general public, begins its timeline of "urban life in the eighteenth century" with the following fact: "1700. From the first years of the eighteenth century, the harpsichord enlivened musical tertulias"”2.

\footnotetext{
${ }^{13}$ Archivo Nacional Histórico, Escribanos de Santiago, vol. 10, f. 107 and vol. 8, f. 282v.

${ }^{14}$ We can consider as valid the definition that later appeared in Diccionario de autoridades (Madrid: Real Academia Española, 1732) as a "type of small guitar that is commonly called a tiple".

${ }^{15}$ Archivo Nacional Histórico, Escribanos de Santiago, vol. 26, f. 120v. Cited by Sonia Pinto (2009). I thank the author for providing me access to her text before it was published.

${ }^{16}$ Archivo Nacional Histórico, Escribanos de Santiago, vol. 309, f. 105.

${ }^{17}$ Archivo Nacional Histórico, Escribanos de Santiago, vol. 20, f. 12 and vol. 145, f. 211.

${ }^{18}$ Archivo Nacional Histórico, Escribanos de Santiago, vol. 100, f. 363v. The document is dated 7 July 1635.

${ }^{19}$ Archivo Nacional Histórico, Escribanos de Santiago, vol. 321, ff. 10, 183; and vol. 322, f. 14. (More examples can be found in Fahrenkrog, 2006).

${ }^{20}$ For example, on p. 103 Díaz Meza refers to the harpist and singer as Dominga Muñoz.

${ }^{21}$ As Alfonso Calderón points out in his introduction to Díaz Meza’s book.

${ }^{22}$ http://www.memoriachilena.cl/602/w3-article-3549.html\#cronologia (accessed on 7 November 2014).
} 
This makes it even more important to reflect critically on the way in which this history has been constructed.

\subsection{The Beginning of the Independence (1810)}

The transition from colony to republic began in Chile with an agitated period that spans the creation of the first government junta in 1810 to the signing of the first official act of independence in 1818. Surprisingly, the same discourse reappears that we have analyzed regarding the year 1700, but now applied to the beginnings of the nineteenth century. In this respect Díaz Meza says: "Until this time [1811], brass instruments were unknown; the cornet and the bugle [clarín], so much in use in Spanish America, had not yet arrived to Chile” (Díaz Meza, 1975: p. 226).

An incomprehensible assertion considering that a few pages before he affirmed that a trumpeter named Alonso de Torres played the song Cata el lobo do va Juanica, and in another chapter he indicates that at the beginning of 1664 "the bugles sounded in the distance" announcing the arrival of Governor Meneses to Santiago (Ibid., 75). The only explanation for such a contradiction is that the author is fitting the data that he finds to a preexisting and previously accepted interpretation about the supposed cultural repercussions in the transition from colony to republic.

As expected, documentary evidence also comes to refute his assumption, since we find trumpets, among others, in the hands of Juan Antonio Sánchez Abarca in 1641, Pedro Porter Casanate in 1661, and Sebastián Chaparro in $1679^{23}$. The fact that Sánchez Abarca and Porter Casanate were governors of the province of Chiloé and the whole kingdom of Chile, respectively, seems to reflect the military use of this kind of instrument.

Pereira Salas proposes a similar interpretation to Díaz Meza’s, while situating in 1819—a year after the signing of the act of independence - the beginning of a true musical art. According to him, in this year the Danish merchant Carlos Drewetcke brought "from Europe some collections of symphonies and quartets of Haydn, Mozart, Beethoven, and Cromer [sic, for Krommer], and for the birthday of Rosa O’Higgins, August 30, 1819, held a performance of a Beethoven symphony and Mozart quartet in a public square” (Pereira Salas, 1941: p. 75). Once again, this event represented a quantitative and qualitative leap for local musical life.

Claro Valdés, while with greater moderation, aligns himself with these points of view with the following:

"With the advent of republican life, musical art received new stimulus. A demonstration of this is the issuing of a decree that freed rights to musical scores and instruments, as it was considered that music 'has the precious objective of softening customs'... Another demonstration of this awakening of national music we find in a new resurgence of traditional popular music”. (The italics are mine)

Further on, he added "Santiago concentrated then a great part of the impetus of this cultural resurgence" (Claro Valdés, 1978: pp. 71-72), thus re-editing the question of the absence of a true culture in the previous period.

But perhaps the most interesting thing about this second recycling of the myth is that we not only have historiographic testimonies but also others from actors at the time that confirm the feeling of a brusque pace of cultural progress was already in force in that epoch, as shown in a hymn composed by Bernardo Vera y Pintado for the opening of the National Institute on August 10, 1813:

"The barbarous plan of cruel tyranny ceased:

the dawn of wisdom

was born...

The laws of vile tyranny

are abhorred,

inhuman resources of the

infernal plot...” (Pedemonte, 2009: p. 10).

[Cesó el plan de barbarie

de la cruel tiranía:

de la sabiduría

${ }^{23}$ Archivo Nacional Histórico, Escribanos de Santiago, vol. 140, f. 417; Real Audiencia, vol. 487, ff. 175, 242; and Escribanos de Santiago, vol. 351, ff. 211, 472v. 
la aurora amaneció...

Se aborrecen las leyes

de los viles tiranos,

recursos inhumanos

del infernal complot...]

As I have discussed in another work (Vera, 2006: pp. 146-147), the vision of the colonial era as a period without culture was canonized in the academic ambit with the speech given by José Victorino Lastarria at the Universidad de Chile in its general session of September 22, 1844, which was published during the same year. More than a study, the discourse was a manifesto about the nefarious influence of Spanish domination in cultural terms and the redemptive actions of the republic (Lastarria, 1844; cf. Subercaseaux, 1997: p. 43).

In a strictly musical plane, the claim about 1819 as the moment when musical art began does not pertain originally to Pereira Salas, but rather, as he himself indicates, to the nineteenth-century musician, politician and chronicler, José Zapiola. It was the latter who affirmed in his Recuerdos de treinta años, published originally from 1872 to 1874, that Drewetcke brought the aforementioned symphonies and quartets and that, beginning at that time: "musicians came together certain days of the week, and not without effort, to play some of these compositions, performing the part of the violoncello and providing advice about the art, unknown until then" (Zapiola, 1974: p. 44).

It appears from the quotation that what Zapiola called "art" is in great measure the technique of playing the cello and other instruments, which before that would have been played without method or appropriate techniques. Pereira Salas affirms in this respect that before the Republic "musical art was an improvisation, a mere entertainment; music was played by ear, and the children learned to sing like birds" (Pereira Salas, 1941: p. 155).

A single fact that has passed unnoticed by other scholars is sufficient to put in doubt Zapiola's affirmation: A few lines below he states that it was in this epoch that he began his "first musical studies". Consequently, what actually he is telling us is that true musical art in Chile began with him, thus establishing himself as a precursor. This supports Ángel Rama's belief that these stories from the end of the nineteenth century about the city of the past are not objective texts, but an attempt of literate elite to maintain their hegemony amid the growth of popular masses (Rama, 2004: pp. 126-127).

Once again, a deeper documentary review shows that the importing of musical scores and instruments was not a novelty of the republican period. Customs documents conserved in the section Contaduría Mayor of the Archivo Nacional Histórico reveal that between 1769 and 1799 (unfortunately, there are no records before this) some fifty musical instruments arrived by sea and over the Andes, among them harpsichords, pianos, organs, psalteries, flutes, and a violin, as well as "music papers". In addition, we find a curious "wooden clock with music made in Spain" and some rattles in the records of merchants (Vera, 2010: pp. 24-26). Likewise, analysis of musical scores and the copyists of the cathedral show that musical scores came from Lima, some of them originating from Spain, at the end of the eighteenth century and the beginning of the nineteenth (Vera, 2013). Finally, customs registers of the port of El Callao (Lima) ${ }^{24}$, show the entry in 1787 of an "English harpsichord or fortepiano" (Un clave o fortepiano ingles) and the two musical treatises published in Spain by Pablo Minguet e Yrol (1737, 1752-1754), with destination to Chilean cities: Concepción and Santiago, respectively.

Despite this, the traditional historiography of music in Chile has preferred a different view. The musician and researcher Jorge Urrutia Blondel states that with the Republic "a true history [of music] had only started, which before had only been babbling". He adds that while the process of musical change "was not violent and rapid" as it was in the political sphere, it was "quite notable and, proportionally, much more intense in the first half of the century than the second". However, this change do not occur exactly at the beginning of the nineteenth century, given that "the first ten years after 1800 should be discounted until the great date of 1810", because "it appears quite empty and without particular features", as a "true prolonging of the eighteenth century..." (Claro Valdés \& Urrutia Blondel, 1973: pp. 83-84). Beyond the undoubtedly nationalist fanfare of this last statement, just as in many other works cited in the present article, the image of the Republican period projected by Urrutia Blondel is of a time of opening toward European culture in which Chile modernized in contrast to the previous vacuum (explicit in this case) in cultural and historical terms. The analogy with the characteristics that we have listed for the myth of discovery, and even with the expression of Columbus about indigenous speech (of their "babbling")

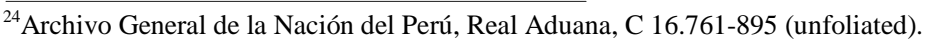


proves surprising.

\subsection{The Centenary of the Republic (1910)}

The first centennial of the Republic of Chile (1910) is one of the moments that have remained branded in Chilean historiography as one of profound transformations and musical changes, since most specialists have not been able to find a link to previous practices. In general, historiography identifies this point as the beginning of symphonism and a true compositional movement in the field of art music, forgetting that many of the supposed "precursors" of this movement active at the beginning of the twentieth century had been formed in the previous period in an operatic tradition, or even smoothly and simply removing works from the historic account that can constitute a nexus with the past. Scholars and people in general have preferred once again, to interpret the change as an absolute rupture with tradition.

According to José Manuel Izquierdo, the promotion undertaken by Domingo Santa Cruz after funding the Bach Society in 1917 contributed to establish the premise that all of the significant innovations occurred in this epoch. It was not by chance that Vicente Salas Viú considered "La muerte de Alsino" (1921) by Alfonso Leng as the first symphonic poem in Chile, when in reality other authors had cultivated the genre several years before $^{25}$.

Santa Cruz himself reaffirmed these ideas years later. In an article published in 1946, after positively evaluating the state of the "contemporary musical movement” in the country, he stated:

"all our musical advance is a recent thing. If twenty years ago someone had said how much musicians would have in their favor in 1946, one would have believed he was talking of utopia... Doctrinally, as well, music has begun to be estimated in a very near epoch because of the effort of a generation that has not long been in the maturity of life” (Santa Cruz, 1946: p. 12) ${ }^{26}$.

He then recognized that had been a certain advance with the arrival of the Republic, but in the end concludes that the real change occurred with centennial and above all with the processes that he himself headed beginning in 1924, the year that the Bach Society began operating as an incorporated body ${ }^{27}$ :

"Until the days of Independence, we have not seriously had a musical past. Nor a civic life, nor a religious one, nor a social one, that offers us anything similar to what existed in Europe or Spain itself at the eighteenth century. The nineteenth century also passed without the cementing of a true musical culture of linking with world centers. Neither the activities of the Conservatory, a school at that time with a very modest range, nor the broad social and governmental support given to the opera succeeded in increasing the narrow circle of music fans, located almost exclusively in the capital... All the distance that had not been traveled to that point had to be covered in a few short years beginning in 1900, or more precisely beginning in 1910, the year of the centennial of Independence. The musical movement of Chile, as has been noted many times, has moved at a breakneck speed and has been accelerating from year to year very vigorously since 1924. "It is wrong to base the evolution of our ambient on the progress and refinement of a group of initiates”, was said publicly on April 1, 1924, at the beginning of the crusade of the Bach Society... The social state that issued these words was no longer that of before. We knew music, the eternal Aida and Rigoletto were no longer enough for us, we wanted culture and we had it... This work, is it of one, three or ten men? No, it is the result of cultural crisis that since the 1920s shook up the whole social, political and ideological panorama in Chile. It is the work of the famous "20s generation" that did not leave things in their place" (Santa Cruz, 1946: pp. 13-14).

Santa Cruz identifies himself and those of his generation as the main agents of these changes, supposedly radicals. In this sense, his attitude reminds us well of Zapiola in 1819, intending to situate himself as a precursor of a true musical art (vid. supra). Europe continues to be the reference in cultural terms, which reproduces the idea of a cultural vacuum before 1910. But Santa Cruz introduces the notion of Chilean composers as musicians without a musical past, an idea that would then be taken up almost word-by-word by Vicente Salas Viú:

\footnotetext{
${ }^{25}$ The author cites the symphonic poem “Másallá de la muerte”, by Luigi Stefano Giarda, the first part of which, “La vida”, was composed in 1913, and the symphonic poem "Fresia” by RaúlHügel, composed in 1910 (Izquierdo, 2011: pp. 34, 37, 43-44).

${ }^{26}$ I owe knowledge of this work to Edgar Vaccaris.

${ }^{27} \mathrm{~A}$ few years later, the author published his personal history of this Society (Santa Cruz, 1950).
} 
"Neither the scarce and precarious religious music of the eighteenth century, nor the salon or civic music of the nineteenth century, nor the Italian opera are the bases that the musical movement in Chile drew upon for it development. There is not even the smallest point of contact between this past and contemporary music. It can be stated categorically that in the realm of musical creation, Chile has no past” (Salas Viú, 1951: p. 25).

Two decades later, Roberto Escobar would confirm this thesis and in some sense would end with consecrating it in his book Músicos sin pasado, referring to art music in Chile in the twentieth century:

"What appears to be a characteristic of Chilean compositional activity in this century is that it developed as a response to cultural requirement of the moment, unlike that of Europe, which evolved driven by a powerful and rich musical past that constituted one of the firmest traditions of its culture. Compared to the Old World, our Chilean composers are musicians without a past. This does not mean that before this there had not been any composition in Chile, given that among all peoples and in every epoch people have created music, but compositional activity began in the twentieth century that was guided by other cultural principles and that conquered a new social role for Chilean composers” (Escobar, 1971: p. 10).

Given the evident concordance between these ideas and the discourses about the discovery, perhaps it would not be an exaggeration to think that the use of the verb "conquer" is more than a mere coincidence.

The persistence of this focus in our days can be confirmed reading assertions such as those that Juan Pablo González dedicated to Pedro Humberto Allende (1885-1959), when he stated that, with his figure:

“Chilean music for the first time is properly situated 'in the space of action' of western music... An important contribution to updating Chilean musicians during the twentieth century was made by the few foreign musicians that had arrived to this faraway land... Thereby, in the decade of 1910 the updating of Chilean musicians and the public on the European musical scene began” (González, 2006: p. 205). (Italics are mine)

The musical history of Chile had begun once again. Allende would have inaugurated a truly western music in these latitudes and this would have a redemptive effect, contributing to overcome the cultural delay and ending with the condition of isolation, which in essence does not differ from other accounts that we have seen in this article about other epochs.

At the same time, the vision of Santa Cruz and friends as protagonists in a rupture with the musical past has been extended to other fields of knowledge. The historians Simon Collier and William F. Sater affirm in 1996: "The institutional framework in which they could work was at first a very fragile one. We cannot talk of a really flourishing musical life in Chile (opera apart) much before the 1940s” (Collier \& Sater, 1996: p. 301; cited by Vaccaris, 2012: pp. 111-112). It seems safe to conjecture at this point that this diagnosis of the past, apparently confined to the field of musicology, has been easily accepted beyond that field because it coincides with the general vision that exists about culture in Chile at the beginning of the twentieth century, and consequently the problems that we address here transcend music and musicology. In any case, a more grounded affirmation about this point requires a review that is beyond the scope of this study.

Despite the undoubted importance of Santa Cruz's discourse, it would be an error to attribute these ideas solely to his influence. As with 1810, we have testimonies from the epoch of the centennial that denote the idea of an abrupt musical change. This is the case of Luis Sandoval, who warned and criticized this process in an article published in 1911, in which he complained that with the coming of Pietro Mascagni, criticism was dedicated to extolling him to the point of forgetting all previous maestros:

"In Europe, the United States and Australia, the critics comb gray hair; here they are as younger and forgetful as possible... As a composer they say of the maestro that he is most illustrious, the greatest, the most celebrated of the Italians that wrote for the theater... As director of operas they say: that he is the most able, the most talented, the most celebrated. And Celestino, Zocchi, Hempel, Contrucci, Antonietti, Padovani, Conti, Goré, Guerrera, Campanini, Anselmi, Polacco, Barone, all maestros that were accepted in our coliseum, what has happened with them now?” (Cited in Varas \& González, 2005: p. 116).

In support of his affirmations, Sandoval referred to the statement of Zapiola already cited, who stated that in 1819 Carlos Drewetcke had already introduced the works of Haydn and other composers, because of which it could not be said that the great works were unknown in Chile by 1910 . He also mentioned the arrivals of Henry 
Howell in 1849 and Gottschalk in 1868 as figures as relevant as Mascagni, adding something very interesting: "in this epoch the chroniclers also exclaimed that never before have we heard anything like this". In other words, Sandoval noticed the contradictory and repetitive aspect of this discourse, although without knowing that the testimony of Zapiola suffered from the same problems that he had found in the musical criticism of his time.

\section{By Way of Conclusion}

Without doubt, there remain many aspects to study such as for example, the possible validity in our day of the aforementioned ideas, in relation to the recent celebration of the bicentennial of the Chilean Republic and of other Latin American countries. This and other points related to the theme go beyond the scope of this work and would require a separate study.

However, what we have seen in the previous pages affirms that the music history of Chile in its different periods has been written until not long ago in a circular manner. In 1700, thanks to the arrival of the Bourbons, the French influence produced a profound cultural and musical change, given the sudden appearance of tertulias and other forms of sociability in which music had an important role. Naturally, these manifestations are in no way linked to the previous century, despite the evidence, including what was known in the times of Díaz Meza and Pereira Salas, could have shown the opposite if they had listened with more attention; but it was often the case that the evidence was accommodated to preexisting interpretations that researchers had about the eighteenth century, despite the pretenses of objectivity that coated their discourse ${ }^{28}$.

The story is more or less the same with 1810: Once again, an important political change, in this case the arrival of the Republic_allowed the opening to Central Europe, with the consequent introduction of supposedly unprecedented musical practices such as the concert and the systematic study of instrumental techniques. Before this in the context of the familiar vacuum, a method of teaching practically did not exist, to the point that "the children learned to sing like birds”, as we have seen in the words of Pereira Salas; and once again the documentary evidence would have been sufficient to show the opposite. What is interesting is that in this case we have testimonies (Zapiola, Vera y Pintado, Lastarria) that show us that these ideas were already valid in the epoch in question. As well, the story has here been given a strongly nationalist coloring ${ }^{29}$, as we have already seen with the efforts of Urrutia Blondel to make the change coincide with the beginning of the Republican period, leaving the first ten years of the nineteenth century relegated to the supposed colonial obscurantism. However, as I pointed out in the introduction, the influence of nationalism does not exclude the hypothesis in relation to the myth of discovery, since as several researchers have for some time argued, historical, social-cultural and therefore musical processes are complex and far from being understandable by considering only one variable (see Adorno, 1999, originally published in 1958).

These nationalist colorings reappear with the same force during the commemoration of the first republican centennial in 1910 and subsequent years and around this, the idea of a previous vacuum also reappears. Music after this time does not have a past with which it is linked and only the gigantic labor of Domingo Santa Cruz and other important figures have allowed real progress in musical terms; an "updating” with Europe as another author termed it, after a long and profound delay since times immemorial, almost beyond history. However, both Sandoval's text and more recent studies allow us to glimpse how unfounded this account is and make us see that, once again, the evidence has been distorted.

In view of all this, I dare to argue that, while we have cited discourses in diverse contexts about three historic periods widely separated in time, we have not really been dealing with different texts, but rather the same text that is recycled over and again to interpret the moments that seem the most relevant in Chilean music history. Every so often music is newly discovered or conquered in Chile, beginning thus a "true history".

But in contrast to what is affirmed by Sandoval, and even by other contemporary authors that have coined the metaphor of a "country without a memory" in relation to more recent tragedies, I think it is not simply a matter of amnesia but rather of the system of concepts and beliefs in which we have become accustomed to situating historical knowledge. A system that in large measure remains anchored to the foundational myth of the discovery and conquest of our continent.

\footnotetext{
${ }^{28}$ Pereira Salas stated about his book: "There are more facts here than doctrines. The author has preferred to let the documents speak instead of filling the gaps with rhetoric and imagination” (Pereira Salas, 1941: p. xviii).

${ }^{29}$ Which, however, was already present in discourses about 1700, as I believe I have shown in a previous work (Vera, 2010).
} 


\section{References}

Adorno, T. W. (1999). Some Ideas on the Sociology of Music. In T. W. Adorno, Sound Figures (pp. 1-14). Stanford, California: Stanford University Press.

Alruiz, C., \& Fahrenkrog, L. (2008). Construcción de instrumentos musicales en el Virreinato del Perú: Vínculos y proyecciones con Santiago de Chile. Resonancias, 22, 43-62.

Carreras, J. J. (2001). Hijos de Pedrell. La historiografía musical española y sus orígenes nacionalistas (1780-1980). Il Saggiatore Musicale, 8, 123-171.

Castillo, G. (1998). Epistemología y construcción identitaria en el relato musicológico americano. Revista Musical Chilena, 52, 15-35.

Castillo, G. (2003). Las estéticas nocturnas. Ensayo republicano y representación cultural en Chile e IberoAmerica. Santiago: Instituto de Estética, Pontificia Universidad Católica de Chile.

Claro Valdés, S. (1978). Oyendo a Chile. Santiago: Editorial Andrés Bello.

Claro Valdés, S., \& Urrutia Blondel, J. (1973). Historia de la música en Chile. Santiago de Chile: Orbe.

Collier, S., \& Sater, W. F. (1996). A History of Chile, 1808-1994. Cambridge: Cambridge University Press.

Díaz Meza, A. (1975). Leyendas y episodios chilenos, vol. 2, En plena colonia. Santiago: Nascimento.

Dussel, E. (1992). 1492: el encubrimiento del otro (hacia el origen del mito de la modernidad). Madrid: Nueva Utopía.

Eliade, M. (1971). The Myth of the Eternal Return: Cosmos and History. Princeton, NJ: Princeton University Press.

Escobar, R. (1971). Músicos sin pasado. Composición y compositores de Chile. Santiago: Editorial Pomaire, Universidad Católica de Chile.

Eyzaguirre, J. (1990). Hispanoamérica del dolor. Santiago: Editorial Universitaria.

Fahrenkrog, L. (2006). El arpa en Santiago de Chile durante la colonia. Undergraduate Thesis, Santiago: Pontificia Universidad Católica de Chile.

Friederici, G. (1986). El carácter del descubrimiento y de la conquista de América. Introducción a la historia de la colonización de América por los pueblos del viejo mundo, Volume 2. México D.F.: Fondo de Cultura Económica.

Fulcher, J. F. (2011). Introduction: Defining the New Cultural History of Music, Its Origins, Methodologies, and Lines of Inquiry. In J. Fulcher (Ed.), The Oxford Handbook of the New Cultural History of Music (pp. 3-14). Oxford: Oxford University Press. http://dx.doi.org/10.1093/oxfordhb/9780195341867.001.0001

Gesualdo, V. (1978). Historia de la música en la Argentina. Buenos Aires: Libros de Hispanoamérica.

Gil, J. (1989). Mitos y utopías del descubrimiento. Madrid: Alianza.

González, J. P. (2006). Música: De la partitura al disco. In C. Gazmuri (Ed.), 100 años de cultura chilena 1905-2005 (pp. 201252). Santiago: Zig-Zag SA.

Grier, J. (1996). The Critical Editing of Music: History, Method and Practice. Cambridge: Cambridge University Press.

Guerra, C. (2008). Tiempo histórico, tiempo litúrgico, tiempo musical: Una escucha entre Paul Ricoeur y la Misa de Chilenía. Ph.D. Thesis, Santiago: Universidad de Chile.

Hutcheon, L. (1988). A Poetics of Postmodernism. History, Theory, Fiction. New York \& London: Routledge. http://dx.doi.org/10.4324/9780203358856

Izquierdo, J. M. (2011). Aproximación a una recuperación histórica: Compositores excluidos, músicas perdidas, transiciones estilísticas y descripciones sinfónicas a comienzos del siglo XX en Chile. Resonancias, 33-47.

Jocelyn-Holt, A. (2004). Historia general de Chile, vol. 2, Los Césares perdidos. Santiago: Editorial Sudamericana.

Kenyon de Pascual, B. (1992). Clavicordios and Clavichords in 16th-Century Spain. Early Music, 20, 611-630. http://dx.doi.org/10.1093/em/XX.4.611

Klein, M. L. (2005). Intertextuality in Western Art Music. Bloomington \& Indianapolis: Indiana University Press.

Lastarria, J. V. (1844). Investigaciones sobre la influencia social de la conquista y del sistema colonial de los españoles en Chile. Santiago: Imprenta del Siglo.

Mayer, A. (1992). El descubrimiento de América en la historiografía norteamericana (siglos XVII al XX). México D.F.: Universidad Nacional Autónoma de México.

Medina, J. T. (1906). Diccionario biográfico colonial de Chile. Santiago: Imprenta Elzeviriana.

Minguet, P. (1737). Arte de danzar a la francesa. Madrid: Pablo Minguet.

Minguet, P. (1752-1754). Reglas y advertencias generales: Que enseñan el modo de tañer todos los instrumentos. Madrid: Joaquín Ibarra.

Morales, N. (2007). L'Artiste de cour dans l'Espagne du XVIIIe siècle. Étude de la communauté des musiciens au service de 
Philippe V(1700-1746). Madrid: Casa de Velásquez.

O'Gorman, E. (2004). La invención de América: Investigación acerca de la estructura histórica del nuevo mundo y del sentido de su devenir. México: Fondo de Cultura Económica.

Pastor, B. (1988). Discursos narrativos de la conquista: mitificación y emergencia. Hanover: Ediciones del Norte.

Pedemonte, R. (2009). “Cantemos la gloria”: Himnos patrióticos e identidad nacional en Chile (1810-1840). In G. Cid, \& A. San Francisco (Eds.), Nación y nacionalismo en Chile. Siglo XIX (pp. 3-38). Santiago: Centro de Estudios Bicentenario.

Pereira Salas, E. (1941). Los orígenes del arte musical en Chile. Santiago de Chile: Universidad de Chile.

Pinto, S. (2009). Testamentos coloniales: Una fuente para la historia social de Chile. Unpublished Paper Given at XVIII Jornadas de Historia de Chile. Valdivia: Universidad Austral.

Rama, Á. (2004). La ciudad letrada. Santiago de Chile: Tajamar Editores Ltda.

Salas Viú, V. (1951). La creación musical en Chile 1900-1951. Santiago: Universidad de Chile.

Salinas, M. (2000). ¡Toquen flautas y tambores!: Una historia social de la música desde las culturas populares en Chile, siglos XVI-XX. Revista Musical Chilena, 54, 45-82.

Santa Cruz, D. (1946). Las masas y la vida musical. Revista Musical Chilena, 2, 11-19.

Santa Cruz, D. (1950). Mis recuerdos sobre la Sociedad Bach. Revista Musical Chilena, 6, 8-62.

Stevenson, R. (1959). The Music of Peru. Aboriginal and Viceroyal Epochs. Washington DC: Pan American Union, General Secretariat of the Organization of American States.

Subercaseaux, B. (1997). Historia de las ideas y de la cultura en Chile, vol. 1, Sociedad y cultura liberal en el siglo XIX: J. V. Lastarria. Santiago: Editorial Universitaria.

Thayer Ojeda, T. (1921). Reseña histórico-biográfica de los eclesiásticos en el descubrimiento y conquista de Chile. Santiago de Chile: Imprenta Universitaria.

Todorov, T. (1984). The Conquest of America. The Question of the Other. New York: Harper \& Row.

Treitler, L. (1990). History and Music. New Literary History, 21, 299-319. http://dx.doi.org/10.2307/469254

Vaccaris, E. (2012). Reformas culturales entre 1925 y 1930. Refundación de la educación musical superior y las artes en Chile. Master’s Thesis, Santiago: Pontificia Universidad Católica de Chile.

Varas, J. M., \& González, J. P. (2005). En busca de la música chilena. Crónica y antología de una historia sonora. Santiago: Publicaciones del Bicentenario.

Vera, A. (2004a). Music in the Monastery of La Merced, Santiago de Chile, in the Colonial Period. Early Music, 32, 376389.

Vera, A. (2004b). Las agrupaciones instrumentales en las ciudades e instituciones "Periféricas” de la Colonia: El caso de Santiago de Chile. In V. Rondón (Ed.), Música colonial iberoamericana: Interpretaciones en torno a la práctica de ejecución y ejecución de la práctica (pp. 107-119). Santa Cruz de la Sierra: APAC.

Vera, A. (2006). Musicología, historia y nacionalismo: Escritos tradicionales y nuevas perspectivas sobre la música del Chile colonial. Acta Musicologica, 78, 139-158.

Vera, A. (2010). ¿Decadencia o progreso? La música del siglo XVIII y el nacionalismo decimonónico. Latin American Music Review, 31, 1-39. http://dx.doi.org/10.1353/lat.2010.0006

Vera, A. (2013). Trazas y trazos de la circulación musical en el virreinato del Perú: Copistas de la catedral de Lima en Santiago de Chile. Anuario Musical, 68, 133-168.

Waisman, L. (2004). La America española: Proyecto y resistencia. In J. Griffiths, \& J. Suárez-Pajares (Eds.), Políticas y prácticas musicales en el mundo de Felipe II (pp. 503-550). Madrid: ICCMU.

Waisman, L. (2005). La música en la definición de lo urbano: Los pueblos de indios americanos. In A. Bombi, J. J. Carreras, \& M. Á. Marín (Eds.), Música y cultura urbana en la Edad Moderna (pp. 159-175). Valencia: Universitat de Vàlencia.

White, H. (1973). Interpretation in History. New Literary History, 4, 288-289. http://dx.doi.org/10.2307/468478

Zapiola, J. (1974). Recuerdos de treinta años (1810-1840). Buenos Aires \& Santiago: Editorial Francisco de Aguirre. 
Scientific Research Publishing (SCIRP) is one of the largest Open Access journal publishers. It is currently publishing more than 200 open access, online, peer-reviewed journals covering a wide range of academic disciplines. SCIRP serves the worldwide academic communities and contributes to the progress and application of science with its publication.

Other selected journals from SCIRP are listed as below. Submit your manuscript to us via either submit@scirp.org or Online Submission Portal.
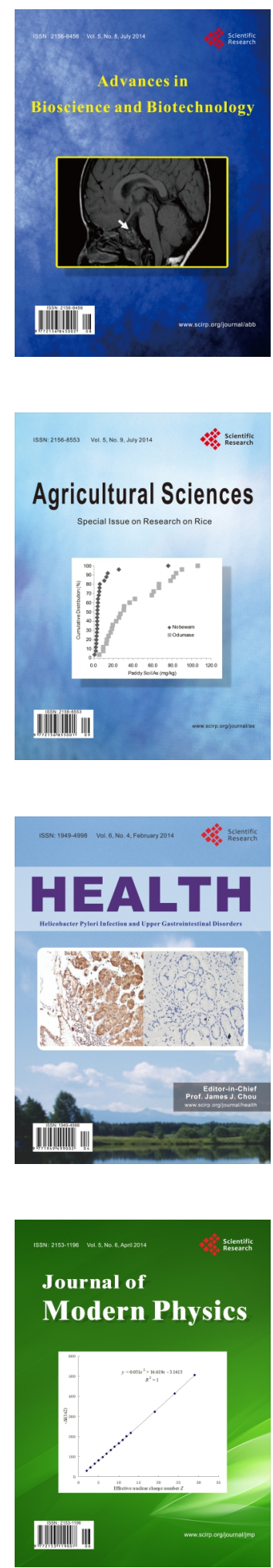
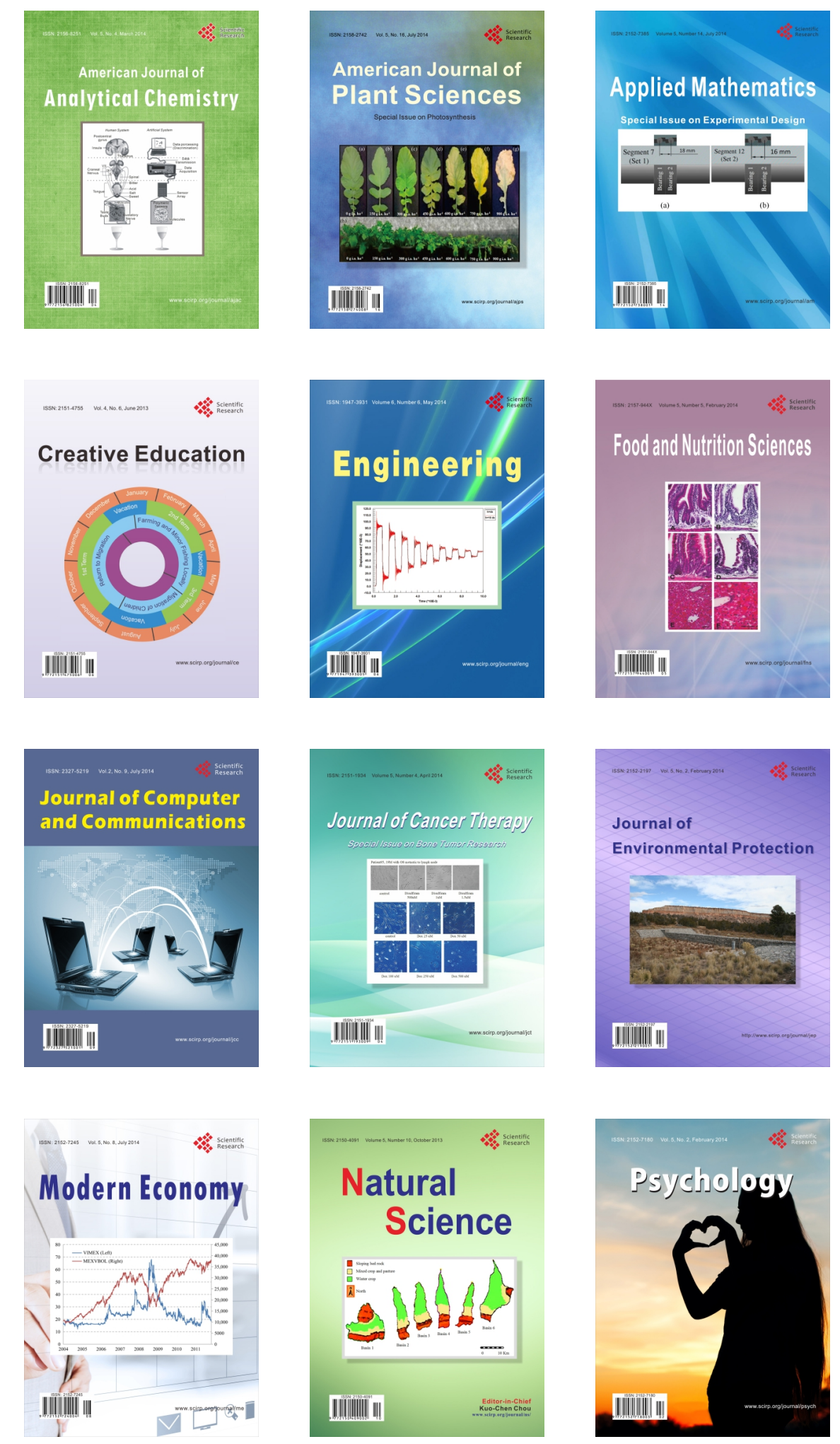